Kelemen József ${ }^{1}$ :

\title{
E-kereskedelem: szállítási díjjal vagy anélkül?² \\ E-commerce: with or without shipping fee?
}

A tanulmány az ingyenes házhozszállítás és a szállítási díjjal való árazás stratégiáját vizsgálja. Egy termék vásárlásakor házhozszállítás esetén felmerül a kérdés, hogy a termék árában benne kell lennie a szállítási díjnak vagy a kettőt szét kell választani, és a termék ára mellett külön meg kell jelennie annak? A probléma elemzéséhez Kelemen [2017b] modelljét alkalmazzuk, amit kiegészítünk a szállítási díjat kifogásoló fogyasztókkal. Egy olyan modellbe helyezzük az elemzést, ami a térbeliséget mélyrehatóbban veszi figyelembe a piac méretén, a szállítási díjon és az utazási költségen keresztül. A szállítási díjjal való árazás magasabb profitot eredményez, azonban ehhez a piacot jól kell ismerni.

This paper studies the free shipping and partitioned pricing strategy (product price with shipping fee). If a product is ordered for delivery, it is not straightforward that the price should consist of the shipping fee or the product price and shipping fee should be separated. We extend the model of Kelemen [2017b] with shipping charge skepticism. In this framework, we can investigate the spatial properties in more detail through the size of the market, the shipping fee and the transportation cost. As a result of that, the partitioned pricing ensures higher profit, but it requires the knowledge of key characteristics of the market.

\section{Bevezetés}

A webáruházak terjedésével párhuzamosan az ezzel kapcsolatos kérdések, mint a házhozszállítási díj is, egyre több kutatót foglalkoztatnak. Egy webáruház számára lényeges szempont, hogy a szállítási költséget milyen módon hárítsa át a vevőkre, milyen stratégia előnyösebb neki. A tanulmányban ennek két alapvető formájáról lesz szó: az ingyenes házhozszállításról, amikor a termék ára tartalmazza a kiszállítást, illetve a szállítási díjjal való árazásról, amikor két különböző ár van, a termék ára és a szállítási díj. Nem meglepő, hogy a szállítási díj vizsgálata a szakirodalomban immár meglehetősen népszerü.

Campanelli [2002] megállapította, hogy a kereskedök egy része a szállitási költségeket áthárítja, így az teljes egészében a vevőket terheli. Tedeschi [2001] szerint továbbá bizonyíték van arra, hogy a vállalatok egy része hasznot húz a kiszállításból. Sőt Enbysk [2005] azt találta, hogy a kereskedőknek több mint fele keres a szállítási díjakon.

Morwitz [1998] szerint a szállítási díjjal való árazás esetén a fogyasztók alábecsülhetik vagy alulértékelhetik a szállítási díjat. Azonban más tanulmányok épp az ellenkezőjét találták. Schindler és szerzőtársai [2005] a fogyasztók preferenciáit vizsgálták a szállítási díjjal való árazás és az ingyenes házhozszállitás esetén és azt figyelték meg, hogy néhány fogyasztó tisztességtelennek találja, amikor extra költségekkel szembesül a termék

\footnotetext{
${ }^{1} \mathrm{PhD}$, Budapesti Corvinus Egyetem

${ }^{2}$ Köszönet a névtelen bírálónak a hasznos megjegyzésekért.

DOI: $10.14267 /$ RETP2021.01.12
} 
árán felül (mint kiszállítási és kezelési költség). Őket nevezzük szállítási díj kifogásolóknak, akik jobban kedvelik, ha csak egyetlen ár van. Léteznek szállítási díj kedvelők is, akik inkább preferálják, ha van külön szállítási díj is. Ez a megállapítás összhangban van Hamilton és Srivastava [2008] eredményével, akik amellett érveltek, hogy a szállitási díjjal való árazáskor a fogyasztók árérzékenyebbek a kisebb összegủ szállítási díjra, mint a nagyobb összegü termékárra.

Lewis és szerzőtársai [2006] a fogyasztók árérzékenységét vizsgálta a különböző árazási stratégiák esetén, valamint, hogy ezek milyen hatással vannak a megrendelés gyakoriságára és a kosár méretére. Az ingyenes házhozszállítás növelte a megrendelések gyakoriságát, viszont kisebb összegủ megrendelésekhez vezetett. Addig az értékhatárhoz kötött ingyenes házhozszállítás ${ }^{3}$ nagyobb megrendelésekkel párosult, viszont a megrendelés gyakoriságára nem volt hatással. A szerzők szerint az ingyenes házhozszállítás nem volt profitábilis a vállalatok számára és veszteségeket eredményezett.

Dinlersoz és Li [2006] az internetes könyvkereskedelem piacán elemezte, hogy a kereskedők milyen árazási stratégiákat használnak. Az elemzésükbe bevették a szállítás minőségét is, amit az átlagos kiszállítási idővel feleltettek meg. A szerzők azt találták, hogy azok az eladók, akik alacsonyabb termékárat kínálnak, magasabb szállítási minőséget biztosítanak és alacsonyabb szállítási díjat kérnek. Ez ellentmondásosnak tűnik, amit a nem tökéletes vásárlói információkkal magyaráztak.

Yao és Zhang [2012] a termékár és a szállítási díj allokációját, valamint a kiszállítási időt vizsgálta egyszerre analitikus és empirikus eszközökkel. Arra jutottak, hogy az ingyenes házhozszállítás növeli az árat, azaz a teljes ár nemcsak a termék árát fedezi, hanem a szállítási díj egy részét is. Továbbá a termékár növekszik a pontos kézbesítés valószínűségével, viszont a szállítási díj közben csökken.

Nevena és szerzőtársai [2012] a népszerü árazási fajtákat és azok hatásait vizsgálta. Az értékhatárhoz kötött ingyenes házhozszállítás értékelése jobb volt, mint az ingyenes házhozszállításé, ha a vásárlók eredetileg is az értékhatár felett akartak vásárolni. Ellenkező esetben az értékelés romlott.

Gümüş és szerzőtársai [2013] szintén az árazási stratégiákat elemezte. A vállalatok számára praktikus választ kerestek arra, hogy vajon jobb-e a kiszállítási és kezelési költségeket a termék árába beépíteni vagy érdemesebb elkülöníteni azt. A szerzők megerősítették, hogy a szállítási díjjal való árazás esetén önmagában a termékár alacsonyabb, míg a kiszállítási és kezelési dijakkal együtt már magasabb, mint az ingyenes házhozszállításnál alkalmazott ár. Az empirikus eredményeik azt mutatták, hogy a népszerü vagy kockázatvállaló vállalatok ingyenes házhozszállitást választanak és az áraikat másfélszer többet változtatják. A szállítási díjjal való árazást legfőképp olyan vállalatok választják, amelyek olyan nagy és nehéz termékekkel kereskednek, amiknek magas a szállítási díja. A szállítási díjjal való árazás esetén a kiszállítási és kezelési díj a teljes árnak a 3-5\%-a. A szerzők szerint az ingyenes házhozszállítás több fogyasztót vonz, de a bevételek alacsonyabbak a szállítási díj hiánya miatt, mint a szállítási díjjal való árazás esetében.

Huang és Cheng [2015] az értékhatárhoz kötött ingyenes házhozszállítást vette górcső alá. Nemcsak a dollárban mért értékhez, hanem a termékek darabszámához kötve is vizsgálták azt. Ez utóbbi nagyobb vásárlási szándékhoz vezetett.

A tanulmány az ingyenes házhozszállítást és a szállítási díjjal való árazási stratégiát elemzi, ehhez Kelemen [2017a; 2017b] modelljét vesszük alapul. A korábbiakhoz képest abban térünk el, hogy most a keresletet

\footnotetext{
${ }^{3}$ Az értékhatárhoz kötött ingyenes házhozszállítás esetén csak akkor kell szállítási díjat fizetni, ha a vásárlás értéke nem ér el egy meghatározott összeget.
} 
befolyásolja a fogyasztók viselkedése és szokásai. Egyfelől nem érzékelik tökéletesen a szállítási díjat, másfelől lehetnek szállítási díj kifogásolók, akik érzékenyek a tisztességes szállítási díjtól való eltérésre.

Mivel a térbeli tulajdonságokra összpontosítunk az árazási stratégiák vizsgálatakor, ezért a bemutatásra kerülő modell lényegesen eltér a korábbi hasonló modellektől. Yao és Zhang [2012] a kiszállítási idő fontosságát hangsúlyozza, ezt egy sztenderd és egy gyorsított kiszállítás lehetőségével ragadja meg. Gümüş és szerzőtársai [2013] egy exponenciális keresleti függvényt használnak, azonban ők is figyelembe veszik a szállítási díjat kifogásoló fogyasztókat.

A tanulmány a következő részekre tagolódik. Először a modell kerül ismertetésre, úgy mint a fontosabb paraméterek és a profitmaximalizálás, ezután pedig a modell érzékenységvizsgálata következik. Végül az utolsó rész egy összegzéssel zár.

\section{Modell}

Tegyük fel, hogy van $n$ különböző méretü, $\delta^{i}$ hosszúságú lineáris piac vagy képzeletbeli város. Egyfelől két hagyományos bolt van minden $i$. piacon, az elsőt $A^{i}$-nek, a másodikat $B^{i}$-nek hívják. $A^{i}$ és $B^{i}$ nem versenyeznek egymással, mert piacaik közé olyan fogyasztók ékelödnek be, akik a webáruháztól vásárolnak. A két hagyományos bolt elhelyezkedése rendre $x_{A} i$ és $x_{B} i$. Másfelöl egyetlenegy webáruház van az összes $n$ darab piacon. Egy kétlépcsős játékban $A^{i}$ és $B^{i}$ először meghatározzák az elhelyezkedésüket a képzeletbeli városokban, majd ezután a két bolt és a webáruház dönt az árakról $\left(p_{A} i, p_{B} i\right.$ és $\left.p_{0}\right)$ ugyanarra a termékre vonatkozóan. ${ }^{4}$

A piacon a boltok úgy osztozkodnak, hogy azt balról jobbra haladva a következő sorrendben birtokolják: webáruház, $A^{i}$ bolt, webáruház, $B^{i}$ bolt és újra a webáruház (1. ábra). A széleket és a központot a webáruház szolgálja ki, mivel az ára elég alacsony ahhoz, hogy ezt biztosítani tudja. A fogyasztó abban a boltban vásárol, ahol a termék olcsóbb, ezért léteznek közömbös fogyasztók, akik számára indifferens, hogy a hagyományos boltot vagy a webáruházat választják. A boltok elhelyezkedését egy Nash-egyensúly biztosítja, aminek létezését Economides [1984] látta be. A webáruház ára a hagyományos boltok számára egy rezervációs árként jelenik meg, így azok egymástól elkülönülten tudnak tevékenykedni. ${ }^{5}$

\footnotetext{
${ }^{4}$ Az alsó indexben a nulla a webáruházra vonatkozik.

${ }^{5}$ Fontos megjegyezni, hogy az adott piaci struktúra biztosítja a webáruház jelenlétét. Azaz ha a hagyományos boltok közvetlenül egymással versenyeznének, mert olyan magas lenne a rezervációs ár, akkor a webáruház jelen keretek között nem lépne be és visszakapnánk az eredeti Hotelling-modellt.
} 


\section{1. ábra: Az $i$. piac szerkezete}

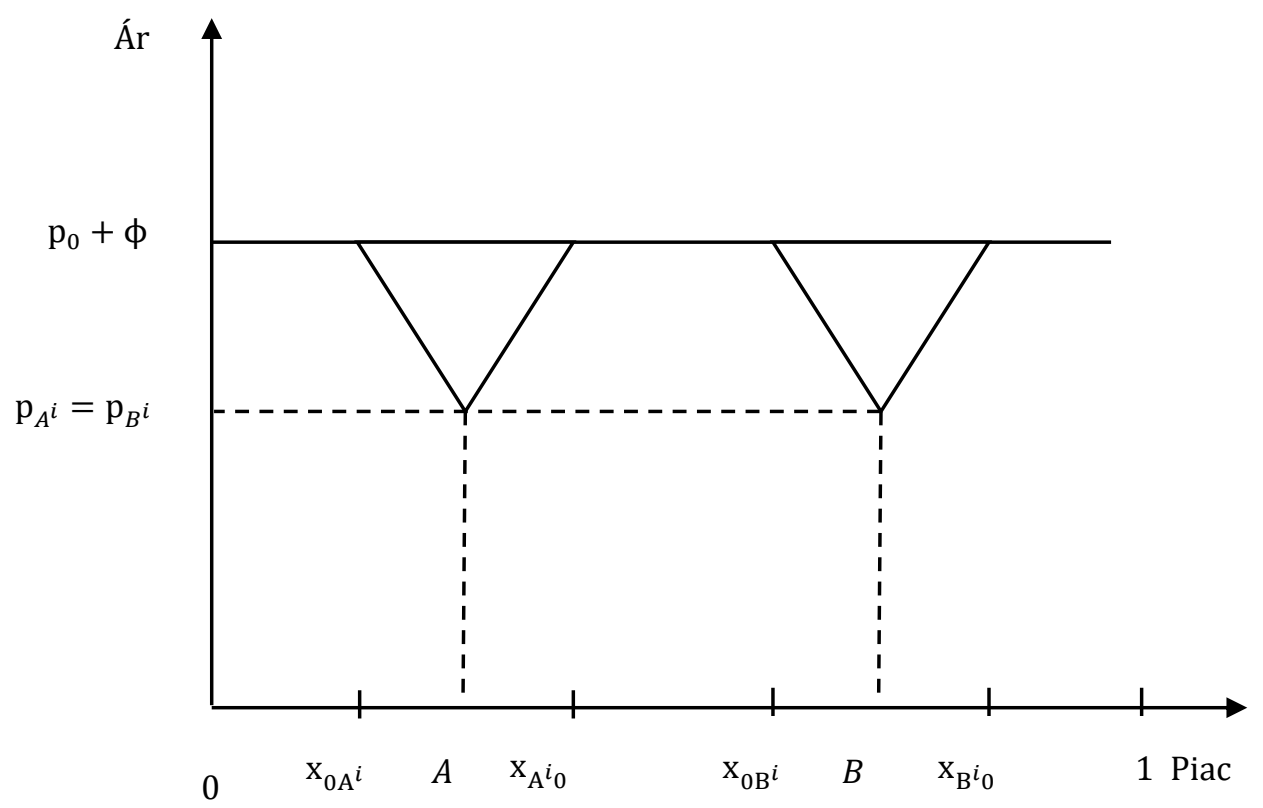

A fogyasztóknak az áron felül még utazási költséget $(\tau>0)$ kell fizetniük, ha a hagyományos boltokban akarnak vásárolni, míg a webáruház egy fix kiszállítási költséggel $(\theta>0)$ szembesül, ha a fogyasztók az interneten vásárolnak. Azonban a webáruház szállítási díjat $(\phi)$ kérhet a fogyasztóktól azért, hogy fedezze a kiszállítási költséget.

Ha meg akarjuk határozni az első közömbös fogyasztó elhelyezkedését, azaz az $A^{i}$ bolt bal oldalán lévőét, akkor a következő egyenletet kell megoldani: $p_{0}+\phi=p_{A} i+\tau\left(x_{A} i-x_{0 A} i\right)$. Ez azt fejezi ki, hogy az ár és a költség azonos az $x_{0 A} i$ pontban lévő közömbös fogyasztó számára, azaz a webáruház ára a kiszállítási költséggel megegyezik az $A^{i}$ bolt árával plusz a hagyományos boltba való utazási költséggel. Azonban most a képlet ettöl eltér:

$$
\mathrm{p}_{0}+\psi_{1} \phi+\psi_{2}\left(\phi-\kappa \mathrm{p}_{0}\right)^{2}=\mathrm{p}_{\mathrm{A}^{\mathrm{i}}}+\tau\left(\mathrm{x}_{\mathrm{A}^{\mathrm{i}}}-\mathrm{x}_{0 \mathrm{~A}^{\mathrm{i}}}\right)
$$

A fogyasztók számára a szállítási díj nem egyértelmủ része az árnak, mivel nem teljesen racionálisak, vagy az információszerzés költsége túl magas számukra. Ez megváltoztatja a vásárlók viselkedését és eltolja a közömbös fogyasztó elhelyezkedését.

A szállítási díj két dologban változott a korábbiakhoz képest az (1) bal oldalán. Az első különbség $\left(\psi_{1} \phi\right)$, hogy a szállítási díj be van szorozva a $\psi_{1}$ paraméterrel, ami a szállítási díj tudatosság. Ez a paraméter azt fejezi ki, hogy a fogyasztók mennyire vannak tudatában a szállítási díjnak, amikor azt a termék ára nem tartalmazza. Ennek az értéke egy 0 és 1 közötti szám $\left(0 \leq \psi_{1} \leq 1\right)$. Amikor nulla, akkor az extra költséget nem veszi észre, amikor egy, akkor teljes mértékben tudatában van annak, hogy szállítási díjat is fizetni kell. De ha a webáruház ismeri ezt a paramétert, akkor magasabb szállítási díjat ad és alacsonyabb termékárat, mert a fogyasztók egy része „be fog dőlni” ennek a trükknek. Így a webáruház egyszerre tudja növelni a keresletét és a profitját. Azonban ez a mechanizmus önmagában egy kiegyensúlyozatlan helyzethez vezetne, például a legextrémebb esetben a termék ingyenes és a szállítási díj az egyetlen ár. Világos, hogy ez a fogyasztók egy részéböl elégedetlenséget váltana ki és otthagynák a webáruházat, más lehetőség után néznének. Így a szállítási díj második tagja $\left(\psi_{2}\left(\phi-\kappa p_{0}\right)^{2}\right)$ a fogyasztók egy olyan csoportját próbálja megragadni, akik tisztességtelenül 
magasnak (vagy értelmetlenül alacsonynak ${ }^{6}$ ) vélik a szállítási díjat, és ezért nem vásárolnak a webáruháztól. A $\psi_{2}$ paraméter ennek a tagnak az érzékenységét jelenti, a zárójelben lévő rész az aktuális szállítási díj eltérése a tisztességes szállítási díjtól, ami a termék árának $\kappa$ százaléka. Ezért $\kappa$ jelenti a tisztességes szállítási díj arányt, míg Schindler és szerzőtársai [2005] után $\psi_{2}$ paraméter a szállítási díj kifogásolóknak a részarányát. Így $\psi_{2}$ és $\kappa$ is 0 és 1 közötti számok $\left(0 \leq \psi_{2}, \kappa \leq 1\right)$.

Átrendezve az (1)-t kifejezhetjük a $x_{0 A} i$ változót, majd ezt hasonlóan megtehetjük a három másik közömbös fogyasztó elhelyezkedésével is:

$$
\begin{aligned}
& \mathrm{x}_{0 A^{\mathrm{i}}}=\frac{1}{\tau}\left(\tau \mathrm{x}_{\mathrm{A}^{\mathrm{i}}}+\mathrm{p}_{\mathrm{A}^{\mathrm{i}}}-\mathrm{p}_{0}-\psi_{1} \phi-\psi_{2}\left(\phi-\kappa \mathrm{p}_{0}\right)^{2}\right) \\
& \mathrm{x}_{\mathrm{A}^{\mathrm{i}} 0}=\frac{1}{\tau}\left(\mathrm{p}_{0}+\psi_{1} \phi+\psi_{2}\left(\phi-\kappa \mathrm{p}_{0}\right)^{2}-\mathrm{p}_{\mathrm{A}^{\mathrm{i}}}+\tau \mathrm{x}_{\mathrm{A}^{\mathrm{i}}}\right) \\
& \mathrm{x}_{0 \mathrm{~B}^{\mathrm{i}}}=\frac{1}{\tau}\left(\tau \mathrm{x}_{\mathrm{B}^{\mathrm{i}}}+\mathrm{p}_{\mathrm{B}^{\mathrm{i}}}-\mathrm{p}_{0}-\psi_{1} \phi-\psi_{2}\left(\phi-\kappa \mathrm{p}_{0}\right)^{2}\right) \\
& \mathrm{x}_{\mathrm{B}^{\mathrm{i}} 0}=\frac{1}{\tau}\left(\mathrm{p}_{0}+\psi_{1} \phi+\psi_{2}\left(\phi-\kappa \mathrm{p}_{0}\right)^{2}-\mathrm{p}_{\mathrm{B}^{\mathrm{i}}}+\tau \mathrm{x}_{\mathrm{B}^{\mathrm{i}}}\right)
\end{aligned}
$$

Az első egyenlet írja le az indifferens fogyasztó elhelyezkedését a webáruház és az $A^{i}$ hagyományos bolt bal oldala között. A többi egyenlet ehhez hasonlóan értelmezhető.

Az első bolt kereslete az $i$. piacon a következőképp fejezhető ki:

$$
\mathrm{q}_{\mathrm{A}^{\mathrm{i}}}=\mathrm{x}_{\mathrm{A}^{\mathrm{i}} 0}-\mathrm{x}_{0 \mathrm{~A}^{\mathrm{i}}}=\frac{2}{\tau}\left(\mathrm{p}_{0}+\psi_{1} \phi+\psi_{2}\left(\phi-\kappa \mathrm{p}_{0}\right)^{2}-\mathrm{p}_{\mathrm{A}^{\mathrm{i}}}\right)
$$

Az általánosság megsértése nélkül feltehetjük, hogy a vállalatoknak nincs termelési és más költsége a kiszállítási költségen kívül:

$$
\pi_{A^{i}}=p_{A^{i}} q_{A^{i}}=p_{A^{i}} \frac{2}{\tau}\left(p_{0}+\psi_{1} \phi+\psi_{2}\left(\phi-\kappa p_{0}\right)^{2}-p_{A^{i}}\right)
$$

A hagyományos boltok árait az elsőrendü feltételek alapján meghatározhatjuk. Mivel ezek nem függnek $i$ indextől, ezért egy általános alsó indexre válthatunk, $r$-re:

$$
\mathrm{p}_{\mathrm{r}}=\mathrm{p}_{\mathrm{A}^{\mathrm{i}}}=\mathrm{p}_{\mathrm{B}^{\mathrm{i}}}=\frac{\mathrm{p}_{0}+\psi_{1} \phi+\psi_{2}\left(\phi-\kappa \mathrm{p}_{0}\right)^{2}}{2}
$$

Továbbá (6) és (8) az optimumban azt eredményezi, hogy

$$
\mathrm{q}_{\mathrm{r}}=\mathrm{q}_{\mathrm{A}^{\mathrm{i}}}=\mathrm{q}_{\mathrm{B}^{\mathrm{i}}}=\frac{2 \mathrm{p}_{\mathrm{r}}}{\tau}
$$

Minden $i$ piacon $B^{i}$ és $A^{i}$ szimmetrikusak, így az összes hagyományos bolt kereslete és ára megegyezik. Világos, hogy két bolt az $i$. piacon $2 q_{r}$ keresletre tesz szert, a maradék a webáruházé. Az $i$. piac mérete $\delta^{i}$ és így ez alapján meghatározható a webáruház profitja a következő módon ${ }^{7}$ :

$$
\pi_{0}=\sum_{\mathrm{i}=1}^{\mathrm{n}}\left(\left(\mathrm{p}_{0}-\theta^{\mathrm{i}}\right)\left(\delta^{\mathrm{i}}-2 \mathrm{q}_{\mathrm{r}}\right)\right)
$$

\section{1. Árazási szabályok}

$\mathrm{Az}$ árakat az ingyenes házhozszállítás és a szállítási díjjal való stratégia esetére határozzuk meg. Analitikusan különbözik a két probléma: az első esetben a profitmaximalizálás egy változó szerint, míg a másodikban két változó szerint történik. Feltételezzük, hogy a webáruház a logisztikát maga végzi.

\footnotetext{
${ }^{6}$ Természetesen a modell eredményei között ez a helyzet nem fog fennállni, mivel a vállalatok nem adnak alacsonyabb szállítási díjat, mint a tisztességes szállítási díj. Ennek a tagnak a szimmetricitása csak az analitikus kezelhetőséget segíti elő.

${ }^{7}$ Meg kell jegyezni, hogy a (9) a Nash esetben még nem behelyettesíthető, csak a (6).
} 
Az eredmények mind Nash, mind Stackelberg verseny esetén léteznek, de a különbségek nem olyan jelentősek: a Nash eset próbálja megragadni a hasonló méretű boltokat, míg a Stackelberg esetben a webáruház mérete nagyobb, mint a hagyományos boltoké és erősebb a piaci ereje is.

\subsubsection{Ingyenes házhozszállítás}

Az ingyenes házhozszállítás egy olyan stratégiát jelent, amikor az eladó egyetlen árat határoz meg, amiért cserébe a vásárló kap egy terméket, amit házhoz is szállítanak. Az ingyenes házhozszállításnak köszönhetően, vagyis, hogy $\phi=0$, a szállítási díj tudatossághoz és a tisztességes szállítási díjhoz kapcsolódó tagot a keresletben nem kell figyelembe venni. A webáruház maximalizál az ár szerint, miközben kiszállítási költsége merül fel. A nagybetük jelentik az ingyenes házhozszállítás, míg a kisbetűk a szállítási díjjal való árazás esetét. Így a profit függvény a következő:

$$
\Pi_{0}=\sum_{\mathrm{i}=1}^{\mathrm{n}}\left(\mathrm{P}_{0}-\theta^{\mathrm{i}}\right)\left(\delta^{\mathrm{i}}-\frac{4}{\tau}\left(\mathrm{P}_{0}-\mathrm{p}_{\mathrm{r}}\right)\right) \rightarrow \max _{\mathrm{P}_{0}}
$$

Az árakat így megkapjuk Nash és Stackelberg verseny esetén ${ }^{8}$

$$
\mathrm{P}_{0}^{\mathrm{N}}=\frac{\mathrm{D}}{6}+\frac{2 \mathrm{H}}{3} \quad \mathrm{P}_{0}^{\mathrm{S}}=\frac{\mathrm{D}}{4}+\frac{\mathrm{H}}{2}
$$

ahol $\mathrm{D}=\frac{\sum_{\mathrm{i}=1}^{\mathrm{n}} \tau \delta^{\mathrm{i}}}{\mathrm{n}}$, továbbá $\mathrm{H}=\frac{\sum_{\mathrm{i}=1}^{\mathrm{n}} \theta^{\mathrm{i}}}{\mathrm{n}}$.

A két képlet hasonló. Az árak a piac átlagos méretének és az átlagos kiszállítási költségnek a súlyozott átlagától függenek. Ez kifejezi, hogy a térbeli változók határozzák meg az árat, amikor nincsenek termelési költségek. A Stackelberg esetben a piac súlya nagyobb, míg a Nash esetben a kiszállítási költség súlya. Belátható, hogy a teljes ár a Stackelberg esetben magasabb, mint a Nash esetben, mint ahogy az várható is. A hagyományos boltok árait a (9) segítségével kaphatjuk meg:

$$
\mathrm{P}_{\mathrm{r}}^{\mathrm{N}}=\frac{\mathrm{D}}{12}+\frac{\mathrm{H}}{3} \quad \mathrm{P}_{\mathrm{r}}^{\mathrm{S}}=\frac{\mathrm{D}}{8}+\frac{\mathrm{H}}{4} .
$$

\subsubsection{Szállítási díjjal való árazás}

A szállítási díjjal való árazási stratégia esetén külön van a termék ára és külön a szállítási díja. Ez a kettő együtt kerül meghatározásra a profitmaximalizáláskor, miközben a fogyasztók alábecsülhetik a szállítási díjat, vagy szállítási díj kifogásolók lehetnek, ezzel befolyásolva a keresletet. A vállalat maximalizálja a profitját az áron és a szállítási díjon keresztül:

$\pi_{0}=\sum_{\mathrm{i}=1}^{\mathrm{n}}\left(\left(\mathrm{p}_{0}+\phi-\theta^{\mathrm{i}}\right)\left(\delta^{\mathrm{i}}-\frac{4}{\tau}\left(\mathrm{p}_{0}+\psi_{1} \phi+\psi_{2}\left(\phi-\kappa \mathrm{p}_{0}\right)^{2}-\mathrm{p}_{\mathrm{r}}\right)\right)\right)$

Miután az elsőrendű feltételeket kiszámoljuk a Nash és Stackelberg esetben, a következő összefüggést kapjuk:

$$
\mathrm{T}=\phi-\kappa \mathrm{p}_{0}=\frac{1-\Psi_{1}}{2 \Psi_{2}(1+\kappa)} .
$$

\footnotetext{
${ }^{8} \mathrm{~A}$ levezetések a függelékben találhatók.
} 
$T$ jelöli az eltérést a tisztességes szállítási díjtól. Ha $\psi_{1}=1$, akkor $T=0$, vagyis a fogyasztók teljesen racionálisak és ök csak a tisztességes szállítási díjat hajlandóak kifizetni. De nem mindig ez a helyzet, ez a tag általában nem nulla, hanem egy pozitív érték. Így a webáruháznak megéri nagyobb szállítási díjat meghatároznia, mint a tisztességes szállítási díj, mivel a veszteség kisebb, mint a nyereség azokon a fogyasztókon, akik nem érzékelik tökéletesen a szállítási díjat. Ahogy $\psi_{1}, \psi_{2}$ és $\kappa$ csökken, úgy nő $T$, azaz ahogy a fogyasztók egyre kevésbé törődnek a szállítási díjjal, úgy tud a webáruház ebből többet profitálni.

Továbbá az is világos, hogy a teljes ár megegyezik a termék árával, a tisztességes szállítási díjjal és az eltérési $T$ változóval.

$$
\mathrm{p}_{0}+\phi=(1+\kappa) \mathrm{p}_{0}+\mathrm{T}
$$

A Nash esetben kombinálva az első két elsőrendű feltételt kiszámolhatjuk a termékárat, majd utána megkaphatjuk a teljes árat.

$$
\begin{gathered}
\mathrm{p}_{0}^{\mathrm{N}}=\frac{\mathrm{D}}{6\left(1+\psi_{1} \kappa\right)}+\frac{2 \mathrm{H}}{3(1+\kappa)}-\frac{5}{6} \frac{1}{1+\kappa} \mathrm{T}-\frac{\psi_{1}}{6\left(1+\psi_{1} \kappa\right)} \mathrm{T} \\
\mathrm{p}_{0}^{\mathrm{N}}+\phi^{\mathrm{N}}=\frac{1+\kappa}{1+\kappa \psi_{1}} \frac{\mathrm{D}}{6}+\frac{2 \mathrm{H}}{3}+\frac{1-\psi_{1}}{6\left(1+\psi_{1} \kappa\right)} \mathrm{T}
\end{gathered}
$$

Együtt a (8) és (16) adja meg a hagyományos boltok optimális árát:

$$
\mathrm{p}_{\mathrm{r}}^{\mathrm{N}}=\frac{\mathrm{D}}{12}+\frac{1+\psi_{1} \kappa}{1+\kappa} \frac{\mathrm{H}}{3}-\psi_{2} \frac{\mathrm{T}^{2}}{3}
$$

A Stackelberg árak analóg módon meghatározhatók.

$$
\begin{gathered}
\mathrm{p}_{0}^{\mathrm{S}=} \frac{\mathrm{D}}{4\left(1+\psi_{1} \kappa\right)}+\frac{\mathrm{H}}{2(1+\kappa)}-\frac{3}{4(1+\kappa)} \mathrm{T}-\frac{\psi_{1}}{4\left(1+\psi_{1} \kappa\right)} \mathrm{T} \\
\mathrm{p}_{0}^{\mathrm{S}+\phi^{\mathrm{S}}}=\frac{1+\kappa}{1+\kappa \psi_{1}} \frac{\mathrm{D}}{4}+\frac{\mathrm{H}}{2}+\frac{1-\psi_{1}}{4\left(1+\psi_{1} \kappa\right)} \mathrm{T} \\
\mathrm{p}_{\mathrm{r}}^{\mathrm{S}}=\frac{\mathrm{D}}{8}+\frac{1+\psi_{1} \kappa}{1+\kappa} \frac{\mathrm{H}}{4}-\psi_{2} \frac{\mathrm{T}^{2}}{4}
\end{gathered}
$$

Egyrészt vegyük észre, hogy az árak függenek az átlagos kiszállítási és utazási költségtől. Viszont a szállítási díj kifogásolók miatt új tagok is megjelennek. A webáruház alacsonyabb alapárat határoz meg az ingyenes házhozszállításhoz képest, hogy becsapja a vevők egy részét. Így ugyanazért a termékért összességében nagyobb árat tud meghatározni, mert a vásárlók nem veszik észre a magasabb szállítási díjat. Ezzel szemben a hagyományos boltok árat csökkentenek, mert a fogyasztók az alacsonyabb alapárral hasonlítják össze a saját áraikat. Gümüş és szerzőtársai [2013] eredményei összhangban vannak ezzel.

Továbbá érdemes megjegyezni, hogy a szállítási díjat és az utazási költséget befolyásolják a $\psi_{1}$ és $\kappa$ paraméterek. Tehát a térbeli paramétereken keresztül is hatnak a szállítási díj kifogásolók és a szállítási díj tudatosság.

A $\psi_{1}=1$ esetben a fogyasztók mindegyike tisztában van a szállítási díjjal és annak mértékével. Könnyen belátható, hogy ekkor $T=0$, így a webáruház szállítási díja a tisztességes szállítási díj, ezért a szállítási díj kifogásolókkal nem kell számolni. Következésképp az ingyenes házhozszállítás és a szállítási díjjal való árazás esete megegyezik, azaz $P_{0}=p_{0}+\phi$, ami a hagyományos boltok áraira is igaz, $P_{r}=p_{r}$.

A modellnek egy speciális esete, amikor a $\psi_{1}$ paramétert a fogyasztók racionalitásának tekintjük. Ekkor $\psi_{2}$ $=1-\psi_{1}$ az irracionalitás mértéke, így $\psi_{2}$ továbbra is a $(0,1)$ intervallumban marad. Ha a fogyasztók teljesen racionálisak, $\psi_{1}=1$, akkor $\psi_{2}=0$ és elvárják, hogy a vállalat a tisztességes szállítási díjat alkalmazza. Ha teljesen irracionálisak, akkor $\psi_{1}=0$ és $\psi_{2}=1$, akkor a vállalat teljes egészében ki tudja a fogyasztókat használni, 
mert azok nem foglalkoznak a szállítási díjjal. Ekkor a tisztességes szállítási díjtól való eltérés csak $\kappa$ változótól függ, mivel $\mathrm{T}=\frac{1}{2(1+\kappa)}$.

Egy másik speciális eset, amikor a tisztességes szállítási díj nem a termékár aránya, hanem egy rögzített értéke, ekkor $\kappa=\frac{\mathrm{d}}{\mathrm{p}_{0}}$. Ez azt eredményezné, hogy $\phi=\frac{1-\Psi_{1}}{2 \psi_{2}}+\mathrm{d}$, ahol $d$ a kívánt szintje a tisztességes szállítási díjnak. Ebben az esetben a webáruház szintén eltér a tisztességes szállítási díj szinttől, ha $\psi_{1} \neq 1$, hogy több profitot szerezzen. A kifejezéseknek egyszerübb alakja van ebben az esetben, mert a szállítási díj nem függ a termékártól, de az eredmények hasonlók az azonos ösztönzők miatt.

A vállalatok elhelyezkedésére továbbra is Kelemen [2017b] állításai állnak fenn, azaz

$$
\begin{aligned}
& \mathrm{x}_{\mathrm{A}^{\mathrm{i}}} \in\left(\frac{\mathrm{q}_{\mathrm{r}}^{*}}{2}, \delta^{\mathrm{i}}-\frac{3 \mathrm{q}_{\mathrm{r}}^{*}}{2}\right) \\
& \mathrm{x}_{\mathrm{B}^{\mathrm{i}}} \in\left(\frac{3 \mathrm{q}_{\mathrm{r}}^{*}}{2}, \delta^{\mathrm{i}}-\frac{\mathrm{q}_{\mathrm{r}}^{*}}{2}\right)
\end{aligned}
$$

Egyrészt az $A^{i}$ vállalatnak bal oldalról kell legalább $\frac{q_{r}^{*}}{2}$ hely. Másrészt korlátozza a jobb oldalán a $B^{i}$ vállalat, így $A^{i}$-nek legalább $\frac{q_{r}^{*}}{2}$ távolságra kell lennie $B^{i}$ utolsó fogyasztójától. De tudjuk, hogy $B^{i}$-nek szintén $q_{r}$ kereslete van a szimmetricitás miatt, így a legvégső elhelyezkedés az $A^{i}$ vállalat számára balra a $\delta^{i}-\frac{q_{r}^{*}}{2}$ ponttól van. Ehhez hasonlóan értelmezhető a $B^{i}$ vállalat.

\subsection{Az optimum szükséges feltételei}

A következő feltételek a profitmaximalizálás szükséges feltételeit tartalmazzák. Először is a webáruház ára ismét pozitív kell, hogy legyen $\left(P_{0}, p_{0}>0\right)$, ami már implikálja azt is, hogy a hagyományos boltoknak pozitív az ára és a szállítási díj is pozitív a (8) és (15) alapján.

Továbbá feltételeznünk kell a piacméret korlátot, azaz a kereslet elég nagy minden piacon a két hagyományos bolt számára, azaz $\delta^{\mathrm{i}}-2 \mathrm{q}_{\mathrm{r}}^{*}>0$ vagy $\delta^{i} / q_{r}^{*}>2$. A kifejezés bal oldala jelenti azt, hogy hány hagyományos bolt tud a piacra belépni. Ha teljesen precízek akarunk lenni, akkor fel kell tételeznünk azt is, hogy háromnál kisebbnek kell lennie. Ez a feltétel kizárja, hogy új hagyományos boltok akarjanak belépni a piacra.

$$
3>\frac{\tau \delta^{\mathrm{i}}}{2 \mathrm{p}_{\mathrm{r}}}>2
$$

Végül pedig nyilvánvaló, hogy a webáruház azokról a piacokról kilép, ahol nem tud profitot termelni. Ebből következik, hogy a legmagasabb kiszállítási költségnek alacsonyabbnak kell lennie, mint a webáruház teljes árának:

$$
\mathrm{P}_{0}>\max \theta^{\mathrm{i}} \quad \mathrm{p}_{0}+\phi>\max \theta^{\mathrm{i}}
$$

\section{Eredmények}

Az eredmények bemutatásakor elég csak a szállítási díjjal való árazásra fókuszálni, mert ennek -mint láttukspeciális esete az ingyenes házhozszállítás. Érzékenységvizsgálatot készítünk a modell változóira. Ezután a modell néhány alapvető tulajdonságát és következményét mutatjuk be. 
A piac méretével $\left(\delta^{i}\right)$ pozitívan korrelál minden ár - a hagyományos boltok árai, az ingyenes házhozszállítás ára, a szállítási díjjal való árazásban a termék ára és a szállítás díja. Nyilvánvaló, hogy ahogy a kereslet növekszik, a vállalatok árat tudnak emelni, és így a profitok is nőnek.

A kiszállítási költség $\left(\theta^{i}\right)$ emelkedése növeli a webáruház költségeit, így az árait meg kell emelnie, hogy a profitabilitását fenn tudja tartani. Nemcsak a termékár, hanem a szállítási díj is emelkedik, mivel a magasabb termékár magasabb tisztességes szállítási díjhoz vezet. A hagyományos boltok követik a webáruház áremelését, hiszen a webáruház kárára nő a keresletük, és így extra profithoz jutnak. Azonban a webáruház nem tudja kompenzálni a csökkenő keresletet, így a profitja visszaesik.

Az utazási költség $(\tau)$ pont ellenkező módon hat a profitokra, mint a kiszállítási költség. A növekedése mérsékli a hagyományos boltok keresletét, így több fogyasztó vásárol a webáruháztól. A webáruház árat emel, amit a hagyományos boltok is követnek. Ezzel egy időben a webáruház profitja emelkedik, míg a hagyományos boltoké csökken. A magasabb utazási költség a webáruháznak előnyt jelent, mert korlátozza a fogyasztókat, hogy elérjék a hagyományos boltokat.

A korábban kapott eredményekben a $D$ változóban a piacméret változója be van szorozva az utazási költséggel, így ha zérus lenne az utazási költség, akkor a piacméret hatás is megszünne. Ellentmondásnak látszik, hogy az utazási költség eltünésével a kiszállítási költség nem változott meg, vagyis, hogy a kettő között nincs kapcsolat. Ennek a problémának a feloldására egy közös szállítási költség faktort lehet bevezetni, ehhez viszont kissé módosítani kell a modellt. Legyen $\tau\left(p_{\tau}\right)=p_{\tau} t_{\tau}$ és $\theta\left(p_{\tau}\right)=p_{\tau} t_{\theta}(i)$, ahol $p_{\tau}$ a szállítási költségek kompozit árindexe, valamint $t_{\tau}$ és $t_{\theta}(i)$ az adott területre jellemző kompozit inputigény (munkaóra, anyagszükséglet stb.). Így $p_{\tau}$ csökkenése már egyszerre mérsékli az utazási és kiszállítási költségeket.

Így implicit a benzin, villamosenergia és más szállítási költség ár növekedése az utazási és kiszállítási költség emelkedéséhez vezet. Ez közvetlen módon hat a webáruház keresletének a bővülésére a hagyományos boltok kárára. Így a webáruház növelni tudja az árát, amit a hagyományos boltok követnek. Ebben a helyzetben a hagyományos boltok több profitot is el tudnak érni, ami köszönhető annak, hogy a modellben a fogyasztók bármekkora ár mellett hajlandók vásárolni és így ki sem lépnek a piacról. Azonban a webáruház költségei is nőnek az emelkedő kiszállítási költségek miatt, a profitja az utazási és kiszállítási költség arányától függ. Ha a kiszállítási költség hatása jelentősebb, akkor emiatt veszteség éri a webáruházat, az ellenkező esetben viszont nő a profitja.

A szállítási díjjal való árazáshoz kapcsolódó tényezők szintén fontos szerepet játszanak. A 2. ábra szemlélteti a szállítási díj tudatosságban, a szállítási díj kifogásolók arányában, valamint a tisztességes szállítási díj arányban történt változásokat, továbbá segít az eredmények értelmezésében, amikor nincs analitikus levezetés.

A szállítási díj tudatosság arányának $\left(\psi_{1}\right)$ növekedése alacsonyabb árat eredményez a webáruház számára a kereslet visszaesése miatt. A veszteség a szállítási díjhoz köthető, mert több fogyasztó veszi észre annak jelentőségét. Ezért a webáruház megpróbálja átstrukturálni az árait, növeli a termékárat, míg csökkenti a szállítási díjat. Összességében ezek a tényezők vezetnek a profit csökkenéséhez. A hagyományos boltok nyernek ezen, mivel sok új fogyasztó öket választja, árat tudnak emelni és magasabb profitot érnek el. 
2. ábra. A webáruház és hagyományos boltok ára és profitja a paraméterek függvényében
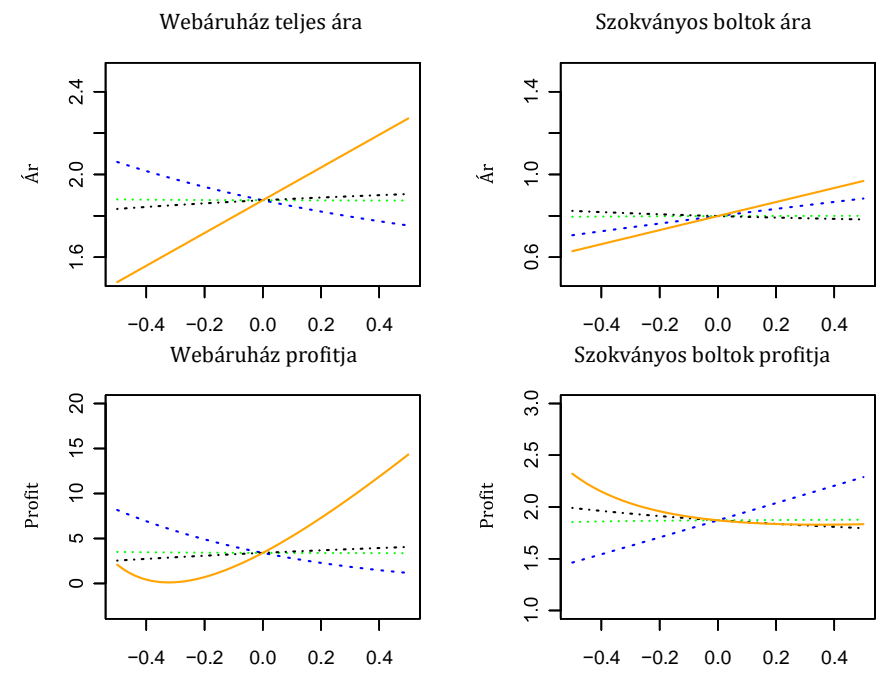

$\begin{array}{ll}\cdots \cdots & \text { Szállítási díj tudatosság } \\ \ldots \ldots . & \text { Szálítási díj kifogásolók aránya } \\ \ldots \ldots & \text { Tisztességes szállítási díj arány } \\ \text { U Utazási költség }\end{array}$

Forrás: saját szerkesztés

Megjegyzés: A vízszintes tengelyen a különböző vonalak az adott paraméter arányos változását mutatják a többi paraméter változatlansága mellett. A függőleges tengely a kapott árakat és profitokat szemlélteti. A webáruház esetén az ár tartalmazza a szállítási díjat. A szélsőséges esetek nem biztos, hogy léteznek, mert a szükséges feltételek lehet, hogy nem teljesülnek.

A szállítási díj kifogásolók arányának $\left(\psi_{2}\right)$ az emelkedése hasonló az előző esethez. A webáruháznak a teljes árát csökkentenie kell, hogy ne veszítseen olyan sok fogyasztót, de nem tudja elkerülni a profit visszaesését. Ez ismét kedvezö a hagyományos boltoknak: árat tudnak emelni, hogy javítsák a profitabilitásukat.

Végül vizsgáljuk meg az árak és a profit összefüggéseit. Könnyen belátható, hogy a szállítási díjjal való árazás esetén a termék ára alacsonyabb, de a teljes ár magasabb, mint az ingyenes házhozszállításkori ár $\left(p_{0}<p_{0}<p_{0}+\phi\right)$. A kapottak összhangban vannak Gümüş és szerzőtársai [2013], valamint Yao és Zhang [2012] eredményeivel.

A kapcsolat nem világos a hagyományos boltok és a webáruház termékeinek ára között. A modell paramétereitől függ, hogy melyik változó értéke magasabb. A hagyományos boltok termékára lehet alacsonyabb, de magasabb is, mint a webáruházé. Ez elsőre ellentmond annak a hétköznapi megfigyelésnek, hogy a webáruházak olcsóbbak a hagyományos boltoknál. Azonban ha jobban végiggondoljuk, feloldható ez a látszólagos ellentmondás. Mivel a modell nem vesz figyelembe olyan tényezőket, mint árak transzparenciája, raktározás, kiszállítás minősége vagy sebessége stb., így fennállhat az a helyzet, hogy bizonyos esetekben egy webáruház magasabb, míg más esetekben alacsonyabb termékárat határoz meg, mint egy hagyományos bolt. Például ha egy hagyományos bolt nagyobb mennyiségben szerez be egy bizonyos terméket, akkor nagyobb kedvezményeket tud kiharcolni, mint egy olyan webáruház, ami külső raktárról szerzi be azt.

Abból, hogy az ingyenes házhozszállitás speciális eset, következik az is, hogy mivel a szállítási díjjal való árazás esetén a webáruház nem választja ezt a stratégiát, így a profit ekkor alacsonyabb. Eszerint a webáruháznak elkülönült árazást kellene alkalmaznia. De fontos megjegyezni, hogy ehhez a webáruháznak ismernie kell az összes releváns piaci információt, paramétert is a profitmaximalizálás során. De valójában ezeket nehéz és költséges összegyüjteni. Így ha egy webáruház nem megfelelő döntést hoz, akkor a profitja 
akár alacsonyabb is lehet az ingyenes házhozszállításkori profitnál. Emiatt az árazási stratégia kiválasztásának a piaci ismereteken kell alapulnia. Egy újonnan induló webáruház számára az ingyenes házhozszállítás ${ }^{9}$ lehet a megfelelő, de a tapasztalatok összegyüjtésével változtathat az árazási stratégiáján.

\section{4. Összegzés}

A szállítási díj témájában napjainkban is számos kutatás folyik. Ez nemcsak elméleti, hanem gyakorlati szempontból is releváns, hiszen a vállalatvezetési döntéseknek egy fontos aspektusa, hogy egy vállalat milyen kiszállítási stratégiát alkalmaz. Ez végső soron a fogyasztói döntéseken keresztül kihat a vállalat profitabilitásra is, és akár a siker kulcsát is jelentheti.

A korábbi modellekben -legjobb tudomásunk szerint- a tér nem volt ilyen részletesen beépítve, továbbá a webáruházzal versenyző hagyományos boltok szintén hiányoztak. Ebben a részben egy térbeli webáruház modell került bemutatásra, amiben olyan paraméterek jelennek meg, mint a piacok mérete, kiszállítási költség és utazási költség. Ezen kívül a webáruházak két általános árazási stratégiáját is megvizsgáltuk, mint az ingyenes házhozszállítást és a szállítási díjjal való árazás. Az utóbbi esetben a szállítási díj miatt új mechanizmusok jelennek meg. Egyfelől a fogyasztók egy része nem elég elővigyázatos, csak a termék árára figyel, így nem foglalkozik (vagy csak részben) a szállítási díjjal. Másfelől vannak fogyasztók (szállítási díj kifogásolók), akik foglalkoznak a szállítási díjjal, van egy elképzelésük a tisztességes szállítási díj szintjéről vagy arányáról, ők otthagyják a webáruházat, ha túl magasnak találják a szállítási díjat.

A tanulmány legfőbb eredményei a modell néhány érdekes tulajdonságát fedik fel. Először is a szállítási díjjal való árazás magasabb profithoz vezet, azonban a piac ismerete szükséges hozzá: a racionális fogyasztók aránya, a szállítási díj kifogásolók aránya és a tisztességes szállítási díj arány. Ez az információ költséges, és ezért az új belépők számára az ingyenes házhozszállítást célszerűbb választani. Másodszor a magasabb kiszállítási költség a hagyományos boltok profitjának növekedéséhez és a webáruház esetében veszteséghez vezet, míg a magasabb utazási költségek ellentétes hatással vannak a profitokra. Ha a két költségnek van egy közös faktora, és emiatt ezek együtt növekednek, akkor a hagyományos boltok mindig nyernek ezen, de a webáruház számára kérdéses a kimenetel, a költségek arányától függ. Például ha az utazási költségek szignifikánsabbak, mint a szállítási költség, akkor a webáruháznak is nő a profitja. Harmadszor az eredmények megerősítik a szakirodalmat, azaz az ingyenes házhozszállítás ára a szállítási díjjal való árazás termékára és teljes ára között van.

\section{Felhasznált irodalom:}

Campanelli, M. (2002): “Who pays to get it there?” In: Entrepreneur. https://www.entrepreneur.com/article/48184 (Letöltés: 2017.06.01.)

Dinlersoz, E. M. and H. Li (2006): "The shipping strategies of internet retailers: Evidence from internet book retailing". In: Quantitative Marketing and Economics 4.4, pp. 407-438.

Economides, N. (1984): “The principle of minimum differentiation revisited”. In: European Economic Review 24.3, pp. 345-368.

Enbysk, M. (2005): “Are your shipping fees driving away customers?” In: Microsoft Small Business Center.

\footnotetext{
${ }^{9}$ Vagy az ezzel ekvivalens szállítási díjjal való árazás, azaz a szállítási díj, a kiszállítási költség és a teljes ár megegyezik az ingyenes házhozszállításkori árral.
} 
https://www.microsoft.com/smallbusiness/issues/technology/ecommerce/\%20are_your_shipping_fees_driving_awa y_customers.mspx (Letöltés: 2017.06.01.)

Gümüş, M. et al. (2013): "Shipping Fees or Shipping Free? A Tale of Two Price Partitioning Strategies in Online Retailing". In: Production and Operations Management 22.4, pp. 758-776.

Hamilton, R. W. and J. Srivastava (2008): "When $2+2$ Is Not the Same as $1+3$ : Variations in Price Sensitivity Across Components of Partitioned Prices". In: Journal of Marketing Research 45.4, pp. 450-461.

Huang, W. and Y. Cheng (2015): “Threshold free shipping policies for internet shoppers". In: Transportation Research Part A: Policy and Practice 82.C, pp. 193-203.

Kelemen, József (2017a): "Note on Hotelling's webshop”. In: Köz-gazdaság, pp. 1075-1089.

Kelemen, József (2017b): “Több piacra épülő webáruház térbeli árversenye”. In: Közgazdasági Szemle 64, pp. 612-629.

Lewis, M., V. Singh, and S. Fay (2006): “An Empirical Study of the Impact of Nonlinear Shipping and Handling Fees on Purchase Incidence and Expenditure Decisions". In: Marketing Science 25.1, pp. 51-64.

Lijesen, M. (2013): “Hotelling's webshop". English. In: Journal of Economics 109.2, pp. 193-200.

Morwitz, V. G., E. A. Greenleaf, and E. J. Johnson (1998): "Divide and Prosper: Consumers' Reactions to Partitioned Prices". In: Journal of Marketing Research 35.4, pp. 453-463.

Nevena, T. K., J. Srivastava, and M. Steul-Fischer (2012): "The effect of shipping fee structure on consumers' online evaluations and choice". In: Journal of the Academy of Marketing Science 40.6, pp. 759-770.

Schindler, R. M., M. Morrin, and N. N. Bechwati (2005): "Shipping charges and shipping-charge skepticism: Implications for direct marketers' pricing formats". In: Journal of Interactive Marketing 19.1, pp. 41-53.

Tedeschi, B. (2001): "E-commerce report; shipping fees: some scrimp, some profit". In: The New York Times. https://www.nytimes.com/2001/06/11/business/e-commerce-report-shipping-fees-some-scrimp-some-profit.html (Letöltés: 2017.06.01.)

Yao, Y. and J. Zhang (2012): "Pricing for shipping services of online retailers: Analytical and empirical approaches". In: Decision Support Systems 53.2, pp. 368-380. 


\section{Függelék}

\section{A. Profitmaximalizálás}

\section{A.1. Elsőrendü feltételek}

\section{A.1.1. Ingyenes házhozszállítás}

A profit függvény általános formája:

$$
\Pi_{0}=\sum_{i=1}^{n}\left(P_{0}-\theta^{i}\right)\left(\delta^{i}-\frac{4}{\tau}\left(P_{0}-p_{r}\right)\right) \rightarrow \max _{P_{0}}
$$

A vállalat egy változó szerint maximalizálja a profitját és így a Nash esetben könnyen kiszámolhatjuk az elsőrendű feltételt és az árat:

$$
\begin{gathered}
\frac{\partial \Pi_{0}^{N}}{\partial \mathrm{P}_{0}}=\sum_{\mathrm{i}=1}^{\mathrm{n}}\left(\left(\mathrm{P}_{0}-\theta^{\mathrm{i}}\right)\left(-\frac{4}{\tau}\right)+\left(\delta^{\mathrm{i}}-\frac{4}{\tau}\left(\mathrm{P}_{0}-\mathrm{p}_{\mathrm{r}}\right)\right)\right)=0 \\
\mathrm{P}_{0}^{\mathrm{N}}=\frac{\sum_{\mathrm{i}=1}^{\mathrm{n}}\left(\tau \delta^{\mathrm{i}}+4 \theta^{\mathrm{i}}\right)}{6 \mathrm{n}}
\end{gathered}
$$

A profit függvény kissé módosul a Stackelberg esetben:

$$
\begin{gathered}
\Pi_{0}^{S}=\sum_{i=1}^{n}\left(P_{0}-\theta^{i}\right)\left(\delta^{i}-\frac{4}{\tau} \frac{P_{0}}{2}\right) \rightarrow \max _{P_{0}} \\
\frac{\partial \Pi_{0}^{S}}{\partial \mathrm{P}_{0}}=\sum_{i=1}^{n}\left(\left(P_{0}-\theta^{i}\right)\left(-\frac{2}{\tau}\right)+\left(\delta^{i}-\frac{2}{\tau}\left(P_{0}-p_{r}\right)\right)\right)=0 \\
P_{0}^{S}=\frac{\sum_{i=1}^{n}\left(\tau \delta^{i}+2 \theta^{i}\right)}{4 n}
\end{gathered}
$$

A másodrendü feltételek triviálisak.

\section{A.1.2. Szállítási díjjal való árazás}

A profit függvény minden paramétert tartalmaz:

$\pi_{0}=\sum_{i=1}^{n}\left(\left(p_{0}+\phi-\theta^{i}\right)\left(\delta^{i}-\frac{4}{\tau}\left(p_{0}+\psi_{1} \phi+\psi_{2}\left(\phi-\kappa p_{0}\right)^{2}-p_{r}\right)\right)\right)$

Az elsőrendű feltételek a Nash esetben:

$\frac{\partial \pi_{0}^{N}}{\partial p_{0}}=\sum_{i=1}^{n}\left(\left(\delta^{i}-\frac{4}{\tau}\left(p_{0}+\psi_{1} \phi+\Psi_{2}\left(\phi-\kappa p_{0}\right)^{2}-p_{r}\right)\right)+\left(p_{0}+\phi-\theta^{i}\right)\left(-\frac{4}{\tau}\left(1+2 \psi_{2}\left(\phi-\kappa p_{0}\right)(-\kappa)\right)\right)\right)=0$

$\frac{\partial \pi_{0}^{N}}{\partial \phi}=\sum_{i=1}^{n}\left(\left(\delta^{i}-\frac{4}{\tau}\left(p_{0}+\Psi_{1} \phi+\Psi_{2}\left(\phi-\kappa p_{0}\right)^{2}-p_{r}\right)\right)+\left(p_{0}+\phi-\theta^{i}\right)\left(-\frac{4}{\tau}\left(\psi_{1}+2 \Psi_{2}\left(\phi-\kappa p_{0}\right)\right)\right)\right)=0$

Kombinálva a két elsőrendű feltételt

$$
1+2 \psi_{2}\left(\phi-\kappa p_{0}\right)(-\kappa)=\psi_{1}+2 \psi_{2}\left(\phi-\kappa p_{0}\right)
$$

megkapjuk az optimális eltérését a szállítási díjnak a tisztességes szállítási díjtól

$$
\mathrm{T}=\phi-\kappa \mathrm{p}_{0}=\frac{1-\psi_{1}}{2 \psi_{2}(1+\kappa)}
$$


Visszahelyettesítve az egyik elsőrendü feltételbe megkapjuk a termék árát:

$$
\begin{aligned}
\mathrm{p}_{0}^{\mathrm{N}}= & \frac{\sum_{\mathrm{i}=1}^{\mathrm{n}} \tau \delta^{\mathrm{i}}}{6 \mathrm{n}\left(1+\psi_{1} \kappa\right)}+\frac{4 \sum_{\mathrm{i}=1}^{\mathrm{n}} \theta^{\mathrm{i}}}{6 \mathrm{n}(1+\kappa)}-\frac{\psi_{1} \mathrm{~T}+\psi_{2} \mathrm{~T}^{2}}{3\left(1+\psi_{1} \kappa\right)}-\frac{2 \mathrm{~T}}{3(1+\kappa)}= \\
& \frac{\sum_{\mathrm{i}=1}^{\mathrm{n}} \tau \delta^{\mathrm{i}}}{6 \mathrm{n}\left(1+\psi_{1} \kappa\right)}+\frac{4 \sum_{\mathrm{i}=1}^{\mathrm{n}} \theta^{\mathrm{i}}}{6 \mathrm{n}(1+\kappa)}-\frac{5}{6} \frac{1}{1+\kappa} \mathrm{T}-\frac{\psi_{1}}{6\left(1+\psi_{1} \kappa\right)} \mathrm{T}
\end{aligned}
$$

A teljes ár könnyen számolható (14) segítségével:

$$
\begin{gathered}
\mathrm{p}_{0}^{\mathrm{N}}+\phi^{\mathrm{N}}=(1+\kappa) \mathrm{p}_{0}+\mathrm{T}=\frac{\sum_{\mathrm{i}=1}^{\mathrm{n}}\left(\frac{1+\kappa}{1+\kappa \psi_{1}} \tau \delta^{\mathrm{i}}+4 \theta^{\mathrm{i}}\right)}{6 \mathrm{n}}+\frac{1-\psi_{1}}{6\left(1+\psi_{1} \kappa\right)} \mathrm{T} \\
\mathrm{p}_{\mathrm{r}}^{\mathrm{N}}=\frac{\mathrm{p}_{0}+\psi_{1} \phi+\psi_{2}\left(\phi-\kappa \mathrm{p}_{0}\right)^{2}}{2}=\frac{\left(1+\psi_{1} \kappa\right) \mathrm{p}_{0}+\psi_{1} \mathrm{~T}+\psi_{2} \mathrm{~T}^{2}}{2}=\frac{\sum_{\mathrm{i}=1}^{\mathrm{n}} \tau \delta^{\mathrm{i}}}{12 \mathrm{n}}+\frac{1+\psi_{1} \kappa}{1+\kappa} \frac{4 \sum_{\mathrm{i}=1}^{\mathrm{n}} \theta^{\mathrm{i}}}{12 \mathrm{n}}-\frac{\Psi_{2} \mathrm{~T}^{2}}{3}
\end{gathered}
$$

A Stackelberg esetben a profit függvény kissé módosul:

$$
\pi_{0}^{\mathrm{S}}=\sum_{\mathrm{i}=1}^{\mathrm{n}}\left(\left(\mathrm{p}_{0}+\phi-\theta^{\mathrm{i}}\right)\left(\delta^{\mathrm{i}}-\frac{2}{\tau}\left(\mathrm{p}_{0}+\psi_{1} \phi+\psi_{2}\left(\phi-\kappa \mathrm{p}_{0}\right)^{2}\right)\right)\right)(
$$

Elsőrendü feltételek:

$$
\begin{gathered}
\frac{\partial \pi_{0}^{S}}{\partial p_{0}}=\sum_{i=1}^{n}\left(\left(\delta^{i}-\frac{2}{\tau}\left(p_{0}+\Psi_{1} \phi+\Psi_{2}\left(\phi-\kappa p_{0}\right)^{2}\right)\right)+\left(p_{0}+\phi-\theta^{i}\right)\left(-\frac{2}{\tau}\left(1+2 \Psi_{2}\left(\phi-\kappa p_{0}\right)(-\kappa)\right)\right)\right)=0 \\
\frac{\partial \pi_{0}^{S}}{\partial \phi}=\sum_{i=1}^{n}\left(\left(\delta^{i}-\frac{2}{\tau}\left(p_{0}+\psi_{1} \phi+\Psi_{2}\left(\phi-\kappa p_{0}\right)^{2}\right)\right)+\left(p_{0}+\phi-\theta^{i}\right)\left(-\frac{2}{\tau}\left(\Psi_{1}+2 \Psi_{2}\left(\phi-\kappa p_{0}\right)\right)\right)\right)=0
\end{gathered}
$$

Visszakapjuk ugyanazt az eltérést a tisztességes szállítási díjtól

A termék ár:

$$
\mathrm{T}=\phi-\kappa \mathrm{p}_{0}=\frac{1-\psi_{1}}{2 \psi_{2}(1+\kappa)}
$$

$$
\begin{gathered}
\mathrm{p}_{0}^{\mathrm{S}}=\frac{\sum_{\mathrm{i}=1}^{\mathrm{n}} \tau \delta^{\mathrm{i}}}{4 \mathrm{n}\left(1+\psi_{1} \kappa\right)}+\frac{2 \sum_{\mathrm{i}=1}^{\mathrm{n}} \theta^{\mathrm{i}}}{4 \mathrm{n}(1+\kappa)}-\frac{\psi_{1} \mathrm{~T}+\psi_{2} \mathrm{~T}^{2}}{2\left(1+\psi_{1} \kappa\right)}-\frac{\mathrm{T}}{2(1+\kappa)}= \\
\frac{\sum_{\mathrm{i}=1}^{\mathrm{n}} \tau \delta^{\mathrm{i}}}{4 \mathrm{n}\left(1+\psi_{1} \kappa\right)}+\frac{2 \sum_{\mathrm{i}=1}^{\mathrm{n}} \theta^{\mathrm{i}}}{4 \mathrm{n}(1+\kappa)}-\frac{3}{4(1+\kappa)} \mathrm{T}-\frac{\psi_{1}}{4\left(1+\psi_{1} \kappa\right)} \mathrm{T}
\end{gathered}
$$

A teljes ár

\section{A.1.3. Másodrendü feltételek}

$$
\begin{gathered}
\mathrm{p}_{0}^{\mathrm{S}}+\phi^{\mathrm{S}}=(1+\kappa) \mathrm{p}_{0}+\mathrm{T}=\frac{\sum_{\mathrm{i}=1}^{\mathrm{n}}\left(\frac{1+\kappa}{1+\kappa \psi_{1}} \tau \delta^{\mathrm{i}}+2 \theta^{\mathrm{i}}\right)}{4 \mathrm{n}}+\frac{1-\psi_{1}}{4\left(1+\psi_{1} \kappa\right)} \mathrm{T} \\
\mathrm{p}_{\mathrm{r}}^{\mathrm{S}}=\frac{\sum_{\mathrm{i}=1}^{\mathrm{n}} \tau \delta^{\mathrm{i}}}{8 \mathrm{n}}+\frac{1+\psi_{1} \kappa}{1+\kappa} \frac{2 \sum_{\mathrm{i}=1}^{\mathrm{n}} \theta^{\mathrm{i}}}{8 \mathrm{n}}-\frac{\psi_{2} \mathrm{~T}^{2}}{4}
\end{gathered}
$$

Másodrendü feltételek a Nash esetben:

$$
\frac{\partial^{2} \pi_{0}^{N}}{\partial^{2} \mathrm{p}_{0}}=\sum_{\mathrm{i}=1}^{\mathrm{n}}\left(-\frac{8}{\tau}\left(1-2 \Psi_{2}\left(\phi-\kappa \mathrm{p}_{0}\right) \kappa\right)-\left(\mathrm{p}_{0}+\phi-\theta^{\mathrm{i}}\right) \frac{8 \Psi_{2}}{\tau} \kappa^{2}\right)
$$




$$
\begin{gathered}
\frac{\partial^{2} \pi_{0}^{N}}{\partial p_{0} \partial \phi}=\sum_{i=1}^{n}\left(-\frac{4}{\tau}\left(\Psi_{1}+2 \Psi_{2}\left(\phi-\kappa p_{0}\right)\right)-\frac{4}{\tau}\left(1-2 \Psi_{2}\left(\phi-\kappa p_{0}\right) \kappa\right)+\left(p_{0}+\phi-\theta^{i}\right) \frac{8}{\tau} \psi_{2} \kappa\right) \\
\frac{\partial^{2} \pi_{0}^{N}}{\partial \phi \partial p_{0}}=\sum_{i=1}^{n}\left(-\frac{4}{\tau}\left(1-2 \Psi_{2}\left(\phi-\kappa p_{0}\right) \kappa\right)-\frac{4}{\tau}\left(\psi_{1}+2 \Psi_{2}\left(\phi-\kappa p_{0}\right)\right)+\left(p_{0}+\phi-\theta^{i}\right) \frac{8}{\tau} \psi_{2} \kappa\right) \\
\frac{\partial^{2} \pi_{0}^{N}}{\partial^{2} \phi}=\sum_{\mathrm{i}=1}^{\mathrm{n}}\left(-\frac{8}{\tau}\left(\Psi_{1}+2 \Psi_{2}\left(\phi-\kappa p_{0}\right)\right)-\left(\mathrm{p}_{0}+\phi-\theta^{\mathrm{i}}\right) \frac{8}{\tau} \Psi_{2}\right)
\end{gathered}
$$

Ismerjük $T$ értékét, de nincs szükségünk $p_{0}$ vagy $\phi$ értékére

$$
\begin{gathered}
\frac{\partial^{2} \pi_{0}^{N}}{\partial^{2} \mathrm{p}_{0}}=-\frac{8}{\tau}\left(\mathrm{En}+\kappa^{2} \mathrm{~F}\right) \\
\frac{\partial^{2} \pi_{0}^{N}}{\partial^{2} \phi}=-\frac{8}{\tau}(\mathrm{Gn}+\mathrm{F}) \\
\frac{\partial^{2} \pi_{0}^{N}}{\partial \mathrm{p}_{0} \partial \phi}=-\frac{4}{\tau}(\mathrm{Gn}+\mathrm{En}-2 \mathrm{~F} \kappa)
\end{gathered}
$$

ahol

$$
\begin{gathered}
E=1-2 \psi_{2} \kappa \mathrm{T}=\frac{1+\kappa \psi_{1}}{1+\kappa}>0 \\
\mathrm{~F}=\Psi_{2} \sum_{\mathrm{i}=1}^{\mathrm{n}}\left(\mathrm{p}_{0}+\phi-\theta^{\mathrm{i}}\right)>0 \\
\mathrm{G}=\Psi_{1}+2 \psi_{2} \mathrm{~T}>0
\end{gathered}
$$

A paraméterek alapján $E$ és $G$ pozitívak, míg azt már korábban feltettük, hogy $\mathrm{p}_{0}+\phi-\theta^{\mathrm{i}}>0$, így $\mathrm{F}$ is pozitív.

Azt kell ellenőrizni, hogy a Hesse mátrix bal felső minorjának determinánsa $\left(D_{1}\right)$ negatív és hogy a Hesse mátrix $\left(H^{N}\right)$ determinánsa pozitív. Ekkor az elsőrendủ feltételek megoldásai lokális maximumok, mert a mátrix negatív definit. Azt egyszerü belátni, hogy $\left|D_{1}\right|<0$ azonban a bonyolultabb eset a $\left|H^{N}\right|>0$.

$$
\begin{aligned}
\left|\mathrm{H}^{\mathrm{N}}\right|=\mathrm{D}_{2}= & \frac{64}{\tau^{2}}\left(\mathrm{En}+\kappa^{2} \mathrm{~F}\right)(\mathrm{Gn}+\mathrm{F})-\frac{16}{\tau^{2}}(\mathrm{Gn}+\mathrm{En}-2 \mathrm{~F} \kappa)^{2}= \\
& \frac{16}{\tau^{2}}\left(4 \mathrm{Fn}(1+\kappa)(\mathrm{G} \kappa+E)-\mathrm{n}^{2}(\mathrm{E}-\mathrm{G})^{2}\right)
\end{aligned}
$$

ahol

$$
\mathrm{G \kappa}+\mathrm{E}=\kappa\left(\psi_{1}+2 \psi_{2} \mathrm{~T}\right)+1-2 \Psi_{2} \kappa \mathrm{T}=1+\kappa \psi_{1}
$$

és

$$
\mathrm{E}-\mathrm{G}=1-2 \psi_{2} \kappa \mathrm{T}-\psi_{1}-2 \psi_{2} \mathrm{~T}=1-\psi_{1}-(1+\kappa) 2 \psi_{2} \frac{1-\psi_{1}}{2 \psi_{2}(1+\kappa)}=0
$$

Az előző feltételeink alapján látható, hogy $D_{2}$ szigorúan pozitív

$$
\mathrm{D}_{2}=\frac{64}{\tau^{2}} \mathrm{Fn}(1+\kappa)\left(1+\kappa \psi_{1}\right)
$$

A Stackelberg eset bizonyítása analóg a Nash esethez. A legfőbb különbség az, hogy a másodrendủ deriváltak feleakkorák, mint az előző esetben, azaz fennáll a Hesse-mátrixra, hogy $\mathrm{H}^{\mathrm{S}}=\frac{1}{2} \mathrm{H}^{\mathrm{N}}$. Mivel csak a (14) egyenletet használtuk az előző bizonyítás során, ami mindkét esetben igaz, így $H^{S}$ szintén negatív definit lesz. 


\section{B. Modellváltozók tulajdonságai}

Ha a bal felső index hiányzik, ami arra utal, hogy Nash vagy Stackelberg eset, akkor az mind a két esetet jelenti.

1. állítás. A teljes Stackelberg ár magasabb, mint a teljes Nash ár.

Bizonyítás. A legmagasabb szállítási költség nagyobb vagy egyenlő a szállítási költségek átlagával. Továbbá a (25) egyenlötlenség alapján

$$
\frac{\sum_{\mathrm{i}=1}^{\mathrm{n}} \theta^{\mathrm{i}}}{\mathrm{n}}=\operatorname{avg}(\theta) \leq \max \left(\theta^{\mathrm{i}}\right) \leq \mathrm{p}_{0}+\phi
$$

Az előző egyenlőtlenséget iteratív módon alkalmazva a Stackelberg árakra a következő eredményhez jutunk:

$$
\begin{aligned}
\mathrm{p}_{0}^{\mathrm{S}}+\phi^{\mathrm{S}}- & \mathrm{p}_{0}^{\mathrm{N}}-\phi^{\mathrm{N}}=\frac{1}{12}\left(\frac{1+\kappa}{1+\psi_{1} \kappa} \frac{\tau \sum_{\mathrm{i}=1}^{\mathrm{n}} \delta^{\mathrm{i}}}{\mathrm{n}}+\frac{1-\psi_{1}}{1+\psi_{1} \kappa} \mathrm{T}\right)-\frac{1}{6} \frac{\sum_{\mathrm{i}=1}^{\mathrm{n}} \theta^{\mathrm{i}}}{\mathrm{n}} \geq \\
& \frac{1}{24}\left(\frac{1+\kappa}{1+\psi_{1} \kappa} \frac{\tau \sum_{\mathrm{i}=1}^{\mathrm{n}} \delta^{\mathrm{i}}}{\mathrm{n}}+\frac{1-\psi_{1}}{1+\psi_{1} \kappa} \mathrm{T}\right)-\frac{1}{12} \frac{\sum_{\mathrm{i}=1}^{\mathrm{n}} \theta^{\mathrm{i}}}{\mathrm{n}} \geq \\
& \frac{1}{48}\left(\frac{1+\kappa}{1+\psi_{1} \kappa} \frac{\tau \sum_{\mathrm{i}=1}^{\mathrm{n}} \delta^{\mathrm{i}}}{\mathrm{n}}+\frac{1-\psi_{1}}{1+\psi_{1} \kappa} \mathrm{T}\right)-\frac{1}{24} \frac{\sum_{\mathrm{i}=1}^{\mathrm{n}} \theta^{\mathrm{i}}}{\mathrm{n}} \rightarrow 0
\end{aligned}
$$

2. állítás. $\frac{\partial \mathrm{p}_{0}}{\partial \delta^{\mathrm{i}}}>0, \frac{\partial \phi}{\partial \delta^{\mathrm{i}}}>0, \frac{\partial\left(\mathrm{p}_{0}+\phi\right)}{\partial \delta^{\mathrm{i}}}>0, \frac{\partial \mathrm{p}_{\mathrm{r}}}{\partial \delta^{\mathrm{i}}}>0, \frac{\partial \pi_{0}}{\partial \delta^{\mathrm{i}}}>0, \frac{\partial \pi_{\mathrm{r}}}{\partial \delta^{\mathrm{i}}}>0$

Bizonyítás. $\frac{\partial \mathrm{p}_{0}^{\mathrm{N}}}{\partial \delta^{\mathrm{i}}}=\frac{\tau}{6 \mathrm{n}\left(1+\psi_{1} \kappa\right)}>0$ és $\frac{\partial \mathrm{p}_{0}^{\mathrm{S}}}{\partial \delta^{\mathrm{i}}}=\frac{\tau}{4 \mathrm{n}\left(1+\psi_{1} \kappa\right)}>0$,

$\frac{\partial \phi}{\partial \delta^{i}}=\left(\kappa p_{0}+T\right)^{\prime}=\kappa \frac{\partial p_{0}}{\partial \delta^{i}}>0$,

A harmadik az előző kettő következménye:

$$
\begin{aligned}
& \frac{\partial \mathrm{pr}_{\mathrm{r}}^{\mathrm{N}}}{\partial \delta^{\mathrm{i}}}=\frac{\tau}{12 \mathrm{n}}>0 \text { és } \frac{\partial \mathrm{p}_{\mathrm{r}}^{\mathrm{S}}}{\partial \delta^{\mathrm{i}}}=\frac{\tau}{8 \mathrm{n}}>0, \\
& \frac{\partial \pi_{0}^{\mathrm{N}}}{\partial \delta^{\mathrm{i}}}=\left(\sum\left(\mathrm{p}_{0}+\phi-\theta^{\mathrm{i}}\right)\left(\delta^{\mathrm{i}}-\frac{4 \mathrm{p}_{\mathrm{r}}}{\tau}\right)\right)^{\prime}=\sum\left(\left(\mathrm{p}_{0}+\phi-\theta^{\mathrm{i}}\right)\left(1-\frac{4 \mathrm{p}_{\mathrm{r}}^{\prime}}{\tau}\right)+\left(p_{0}+\phi\right)^{\prime}\left(\delta^{i}-\frac{4 p_{r}}{\tau}\right)\right)= \\
& \sum\left(\left(\mathrm{p}_{0}+\phi-\theta^{\mathrm{i}}\right)\left(1-\frac{4}{\tau} \frac{\tau}{12 \mathrm{n}}\right)+\frac{1+\kappa}{1+\kappa \psi_{1}} \frac{1}{12 \mathrm{n}}\left(\tau \delta^{\mathrm{i}}-4 \mathrm{p}_{\mathrm{r}}\right)\right)>
\end{aligned}
$$

Felhasználva a (24) egyenlőtlenséget arra a következtetésre jutunk, hogy minden tag nemnegatív:

$$
\sum\left(\left(p_{0}+\phi-\theta^{i}\right)\left(1-\frac{1}{3 n}\right)+\frac{1+\kappa}{1+\kappa \psi_{1}} \frac{1}{12 n}\left(4 p_{r}-4 p_{r}\right)\right)=\sum\left(p_{0}+\phi-\theta^{i}\right)\left(1-\frac{1}{3 n}\right)>0
$$

A Stackelberg eset hasonlóan látható be.

$$
\frac{\partial \pi_{\mathrm{r}}}{\partial \delta^{\mathrm{i}}}=\left(\frac{2 \mathrm{p}_{\mathrm{r}}^{2}}{\tau}\right)^{\prime}=\frac{4 \mathrm{p}_{\mathrm{r}}}{\tau} \mathrm{p}_{\mathrm{r}}^{\prime}=\frac{4 \mathrm{p}_{\mathrm{r}}}{\tau} \frac{\partial \mathrm{p}_{\mathrm{r}}}{\partial \delta^{\mathrm{i}}}>0
$$


3. állítás. $\quad \frac{\partial p_{0}}{\partial \theta^{i}}>0, \frac{\partial \phi}{\partial \theta^{i}}>0, \frac{\partial\left(p_{0}+\phi\right)}{\partial \theta^{i}}>0, \frac{\partial p_{r}}{\partial \theta^{i}}>0, \frac{\partial \pi_{0}}{\partial \theta^{i}}<0, \frac{\partial \pi_{r}}{\partial \theta^{i}}>0$

Bizonyítás. $\quad \frac{\partial \mathrm{p}_{0}^{\mathrm{N}}}{\partial \theta^{\mathrm{i}}}=\frac{4}{6 \mathrm{n}(1+\kappa)}>\mathbf{0}$ és $\frac{\partial p_{0}^{S}}{\partial \theta^{i}}=\frac{2}{4 n(1+\kappa)}>0$,

$\frac{\partial \phi}{\partial \theta^{\mathrm{i}}}=\kappa \frac{\partial \mathrm{p}_{0}}{\partial \theta^{\mathrm{i}}}>0$,

A harmadik az előző kettő következménye:

$$
\begin{aligned}
\frac{\partial \mathrm{p}_{\mathrm{r}}^{\mathrm{N}}}{\partial \theta^{\mathrm{i}}}=\frac{1+\psi_{1} \kappa}{1+\kappa} \frac{1}{12 \mathrm{n}}>0 \text { és } \frac{\partial \mathrm{p}_{\mathrm{r}}^{\mathrm{S}}}{\partial \theta^{\mathrm{i}}}=\frac{1+\psi_{1} \kappa}{1+\kappa} \frac{1}{4 \mathrm{n}}>0, \\
\frac{\partial \pi_{0}}{\partial \theta^{\mathrm{i}}}=\sum\left(\left(\mathrm{p}_{0}+\phi-\theta^{\mathrm{i}}\right)\left(-\frac{4 \mathrm{p}_{\mathrm{r}}^{\prime}}{\tau}\right)+\left(\left(\mathrm{p}_{0}+\phi\right)^{\prime}-1\right)\left(\delta^{\mathrm{i}}-\frac{4 \mathrm{p}_{\mathrm{r}}}{\tau}\right)\right) \\
=\sum\left(\left(\mathrm{p}_{0}+\phi-\theta^{\mathrm{i}}\right)\left(-\frac{4 \mathrm{p}_{\mathrm{r}}^{\prime}}{\tau}\right)+\left(\frac{2}{3 \mathrm{n}}-1\right)\left(\delta^{\mathrm{i}}-\frac{4 \mathrm{p}_{\mathrm{r}}}{\tau}\right)\right)<0
\end{aligned}
$$

A Stackelberg eset hasonlóan látható be.

$\frac{\partial \pi_{r}}{\partial \theta^{i}}=\frac{4 p_{r}}{\tau} p_{r}^{\prime}=\frac{4 p_{r}}{\tau} \frac{\partial p_{r}}{\partial \theta^{i}}>0$

4. állítás. $\quad \frac{\partial p_{0}}{\partial \tau}>0, \frac{\partial \phi}{\partial \tau}>0, \frac{\partial\left(p_{0}+\phi\right)}{\partial \tau}>0, \frac{\partial p_{r}}{\partial \tau}>0, \frac{\partial \pi_{0}}{\partial \tau}>0, \frac{\partial \pi_{r}}{\partial \tau}<0$

Bizonyítás. $\frac{\partial \mathrm{p}_{0}^{\mathrm{N}}}{\partial \tau}=\frac{\sum \delta^{\mathrm{i}}}{6 \mathrm{n}\left(1+\psi_{1} \kappa\right)}>0$ és $\frac{\partial \mathrm{p}_{0}^{\mathrm{S}}}{\partial \tau}=\frac{\sum \delta^{\mathrm{i}}}{4 \mathrm{n}\left(1+\psi_{1} \kappa\right)}>0$,

A második és a harmadik analóg az előző bizonyításhoz.

$$
\begin{gathered}
\frac{\partial \mathrm{p}_{\mathrm{r}}^{\mathrm{N}}}{\partial \tau}=\frac{\sum \delta^{\mathrm{i}}}{12 \mathrm{n}}>0 \text { és } \frac{\partial \mathrm{p}_{\mathrm{r}}^{\mathrm{S}}}{\partial \tau}=\frac{\sum \delta^{\mathrm{i}}}{8 \mathrm{n}}>0, \\
\frac{\partial \pi_{0}^{\mathrm{N}}}{\partial \tau}=\sum\left(\left(\mathrm{p}_{0}+\phi-\theta^{\mathrm{i}}\right)\left(\frac{4 \mathrm{p}_{\mathrm{r}}}{\tau^{2}}-\frac{4 \mathrm{p}_{\mathrm{r}}^{\prime}}{\tau}\right)+\left(\mathrm{p}_{0}+\phi\right)^{\prime}\left(\delta^{\mathrm{i}}-\frac{4 \mathrm{p}_{\mathrm{r}}}{\tau}\right)\right)=\sum\left(\left(\mathrm{p}_{0}+\phi-\theta^{\mathrm{i}}\right) \frac{4}{\tau^{2}}\left(\mathrm{p}_{\mathrm{r}}-\frac{\sum \tau \delta^{\mathrm{i}}}{12 \mathrm{n}}\right)+\right. \\
\left.\left(\mathrm{p}_{0}+\phi\right)^{\prime}\left(\delta^{\mathrm{i}}-\frac{4 \mathrm{p}_{\mathrm{r}}}{\tau}\right)\right)>0,
\end{gathered}
$$

Ez szintén pozitív a (24) egyenlötlenség miatt, mert

$\mathrm{p}_{\mathrm{r}}-\frac{\sum \tau \delta^{\mathrm{i}}}{12 \mathrm{n}}>\mathrm{p}_{\mathrm{r}}-\frac{\sum 6 \mathrm{p}_{\mathrm{r}}}{12 \mathrm{n}}=\left(\mathrm{p}_{\mathrm{r}}-\frac{\mathrm{pr}}{2}\right)=\frac{\mathrm{p}_{\mathrm{r}}}{2}>0$

Újra használhatjuk a (24) egyenlötlenséget.

$$
\frac{\partial \pi_{\mathrm{r}}^{\mathrm{N}}}{\partial \tau}=\frac{4 \mathrm{p}_{\mathrm{r}} \mathrm{p}_{\mathrm{r}}^{\prime}}{\tau}-2 \frac{\mathrm{p}_{\mathrm{r}}^{2}}{\tau^{2}}=\frac{2 \mathrm{p}_{\mathrm{r}}}{\tau}\left(2 \mathrm{p}_{\mathrm{r}}^{\prime}-\frac{\mathrm{p}_{\mathrm{r}}}{\tau}\right)=\frac{2 \mathrm{p}_{\mathrm{r}}}{\tau^{2}}\left(\frac{\sum \tau \delta^{\mathrm{i}}}{6 \mathrm{n}}-\mathrm{p}_{\mathrm{r}}\right)<\frac{2 \mathrm{p}_{\mathrm{r}}}{\tau^{2}}\left(\frac{\sum 6 \mathrm{p}_{\mathrm{r}}}{6 \mathrm{n}}-\mathrm{p}_{\mathrm{r}}\right)=0
$$

A Stackelberg eset hasonló mind a két esetben.

5. állítás. $\quad H a \tau=\boldsymbol{p}_{\tau} \boldsymbol{t}_{\boldsymbol{\tau}} e^{e} \boldsymbol{\theta}^{i}=\boldsymbol{p}_{\tau} \boldsymbol{t}_{\boldsymbol{\theta}}(\boldsymbol{i})$ akkor $\frac{\partial p_{0}}{\partial p_{\tau}}>\mathbf{0}, \frac{\partial \phi}{\partial p_{\tau}}>\mathbf{0}, \frac{\partial\left(p_{0}+\phi\right)}{\partial p_{\tau}}>\mathbf{0}, \frac{\partial p_{r}}{\partial p_{\tau}}>\mathbf{0}, \frac{\partial \pi_{r}}{\partial p_{\tau}}>\mathbf{0}$

Bizonyítás. $\frac{\partial \mathrm{p}_{0}^{\mathrm{N}}}{\partial \mathrm{p}_{\tau}}=\frac{\sum \mathrm{t}_{\tau} \delta^{\mathrm{i}}}{6 \mathrm{n}\left(1+\psi_{1} \kappa\right)}+\frac{4 \sum \mathrm{t}_{\theta}(\mathrm{i})}{6 \mathrm{n}(1+\kappa)}>0$ és $\frac{\partial \mathrm{p}_{0}^{\mathrm{S}}}{\partial \mathrm{p}_{\tau}}=\frac{\sum \mathrm{t}_{\tau} \delta^{\mathrm{i}}}{4 \mathrm{n}\left(1+\psi_{1} \kappa\right)}+\frac{2 \sum \mathrm{t}_{\theta}(\mathrm{i})}{4 \mathrm{n}(1+\kappa)}>0$,

A második és a harmadik analóg az előző bizonyításhoz.

$\frac{\partial \mathrm{p}_{\mathrm{r}}^{\mathrm{N}}}{\partial \mathrm{p}_{\tau}}=\frac{\sum \mathrm{t}_{\tau} \delta^{\mathrm{i}}}{12 \mathrm{n}}+\frac{1+\psi_{1} \kappa}{1+\kappa} \frac{\sum \mathrm{t}_{\theta}(\mathrm{i})}{12 \mathrm{n}}>0$ és $\frac{\partial \mathrm{p}_{\mathrm{r}}^{\mathrm{S}}}{\partial \mathrm{p}_{\tau}}=\frac{\sum \mathrm{t}_{\tau} \delta^{\mathrm{i}}}{8 \mathrm{n}}+\frac{1+\psi_{1} \kappa}{1+\kappa} \frac{\sum \mathrm{t}_{\theta}(\mathrm{i})}{4 \mathrm{n}}>0$ 


$$
\begin{aligned}
& \frac{\partial \pi_{r}^{N}}{\partial p_{\tau}}=\frac{2 p_{r}}{\tau p_{\tau}}\left(2 p_{\tau} p_{r}^{\prime}-p_{r}\right)=\frac{2 p_{r}}{\tau p_{\tau}}\left(p_{\tau} p_{r}^{\prime}+\frac{\Psi_{2} T^{2}}{3}\right)>0 \\
& \frac{\partial \pi_{r}^{S}}{\partial p_{\tau}}=\frac{2 p_{r}}{\tau p_{\tau}}\left(p_{\tau} p_{r}^{\prime}+\frac{\Psi_{2} T^{2}}{4}\right)>0
\end{aligned}
$$

6. álítás. $\quad \frac{\partial\left(p_{0}+\phi\right)}{\partial \psi_{1}}<0, \frac{\partial p_{r}}{\partial \psi_{1}}>0, \frac{\partial \pi_{0}}{\partial \psi_{1}}<0, \frac{\partial \pi_{r}}{\partial \psi_{1}}>0$

\section{Bizonyítás.}

$$
\begin{aligned}
\frac{\partial\left(\mathrm{p}_{0}^{\mathrm{N}}+\phi^{\mathrm{N}}\right)}{\partial \psi_{1}}= & \left(\frac{\sum\left(\frac{1+\kappa}{1+\kappa \psi_{1}} \tau \delta^{\mathrm{i}}+4 \theta^{\mathrm{i}}\right)}{6 \mathrm{n}}+\frac{1-\psi_{1}}{6\left(1+\psi_{1} \kappa\right)} \mathrm{T}\right)^{\prime}=\left(\frac{1+\kappa}{1+\kappa \psi_{1}} \frac{\sum \tau \delta^{\mathrm{i}}}{6 \mathrm{n}}+\frac{\left(1-\psi_{1}\right)^{2}}{\left(1+\psi_{1} \kappa\right)} \frac{1}{12 \psi_{2}(1+\kappa)}\right)^{\prime} \\
& =-\kappa \frac{1+\kappa}{\left(1+\kappa \psi_{1}\right)^{2}} \frac{\sum \tau \delta^{\mathrm{i}}}{6 \mathrm{n}}-\frac{2\left(1-\psi_{1}\right)\left(1+\psi_{1} \kappa\right)+\kappa\left(1-\psi_{1}\right)^{2}}{\left(1+\psi_{1} \kappa\right)^{2}} \frac{1}{12 \psi_{2}(1+\kappa)}<0 \\
\frac{\partial \mathrm{p}_{\mathrm{r}}^{\mathrm{N}}}{\partial \psi_{1}}=\frac{\kappa}{1+\kappa} & \frac{4 \sum \theta^{\mathrm{i}}}{12 \mathrm{n}}+\frac{\left(1-\psi_{1}\right)^{2}}{12 \psi_{2}(1+\kappa)\left(1+\psi_{1} \kappa\right)}>0
\end{aligned}
$$

A Stackelberg esetek hasonlóak

$$
\begin{aligned}
& \frac{\partial \pi_{0}}{\partial \Psi_{1}}=\sum\left(\frac{\partial\left(\mathrm{p}_{0}+\phi\right)}{\partial \psi_{1}}\left(\delta^{\mathrm{i}}-\frac{4 \mathrm{p}_{\mathrm{r}}}{\tau}\right)+\left(\mathrm{p}_{0}+\phi-\theta^{\mathrm{i}}\right)\left(-\frac{4 \mathrm{p}_{\mathrm{r}}^{\prime}}{\tau}\right)\right)<0 \\
& \frac{\partial \pi_{\mathrm{r}}}{\partial \Psi_{1}}=\frac{4 \mathrm{p}_{\mathrm{r}} \mathrm{p}_{\mathrm{r}}^{\prime}}{\tau}>0
\end{aligned}
$$

7. állítás. $\quad \frac{\partial\left(p_{0}+\phi\right)}{\partial \psi_{2}}<0, \frac{\partial p_{r}}{\partial \psi_{2}}>0, \frac{\partial \pi_{0}}{\partial \psi_{2}}<0, \frac{\partial \pi_{r}}{\partial \psi_{2}}>0$

Bizonyítás. $\frac{\partial\left(\mathrm{p}_{0}^{\mathrm{N}}+\phi^{\mathrm{N}}\right)}{\partial \psi_{2}}=-\frac{\left(1-\psi_{1}\right)^{2}}{12\left(1+\psi_{1} \kappa\right)(1+\kappa) \Psi_{2}^{2}}<0$

$\frac{\partial \mathrm{p}_{\mathrm{r}}^{\mathrm{N}}}{\partial \Psi_{2}}=\frac{\left(1-\psi_{1}\right)^{2}}{12 \Psi_{2}^{2}(1+\kappa)^{2}}>0$,

A Stackelberg esetek hasonlóak

$$
\begin{aligned}
& \frac{\partial \pi_{0}}{\partial \psi_{2}}=\sum\left(\frac{\partial\left(\mathrm{p}_{0}+\phi\right)}{\partial \psi_{2}}\left(\delta^{\mathrm{i}}-\frac{4 \mathrm{p}_{\mathrm{r}}}{\tau}\right)+\left(\mathrm{p}_{0}+\phi-\theta^{\mathrm{i}}\right)\left(-\frac{4 \mathrm{p}_{\mathrm{r}}^{\prime}}{\tau}\right)\right)<0, \\
& \frac{\partial \pi_{\mathrm{r}}}{\partial \Psi_{2}}=\frac{4 \mathrm{p}_{\mathrm{r}} \mathrm{p}_{\mathrm{r}}^{\prime}}{\tau}>0
\end{aligned}
$$

\section{8. álítás. $\quad \pi_{0} \geq \Pi_{0}$ és $\pi_{r} \leq \Pi_{r}$}

Bizonyitás. A profitok definíciói:

$$
\pi_{0}=\sum\left(p_{0}+\phi-\theta^{i}\right)\left(\delta^{i}-\frac{4 p_{r}}{\tau}\right), \Pi_{0}=\sum\left(P_{0}-\theta^{i}\right)\left(\delta^{i}-\frac{4 P_{r}}{\tau}\right), \pi_{r}=\frac{2 p_{r}^{2}}{\tau}, \Pi_{r}=\frac{2 P_{r}^{2}}{\tau}
$$

így együtt a webáruház profitjai:

$$
\pi_{0}-\Pi_{0}=\sum\left(\left(\mathrm{p}_{0}+\phi-\theta^{\mathrm{i}}\right)\left(\delta^{\mathrm{i}}-\frac{4 \mathrm{p}_{\mathrm{r}}}{\tau}\right)-\left(\mathrm{P}_{0}-\theta^{\mathrm{i}}\right)\left(\delta^{\mathrm{i}}-\frac{4 \mathrm{P}_{\mathrm{r}}}{\tau}\right)\right)
$$


Ha az egységár mínusz az egységköltség és a kereslet nagyobb, mint az elkülönült esetben, akkor a szorzatuk is nagyobb lesz. Ezért a következő két egyenlötlenség biztosítja az állítás érvényességét

$$
\begin{aligned}
\left(\mathrm{p}_{0}^{\mathrm{N}}+\phi^{\mathrm{N}}-\theta^{\mathrm{i}}\right)-\left(\mathrm{P}_{0}^{\mathrm{N}}+\theta^{\mathrm{i}}\right)=\mathrm{p}_{0}^{\mathrm{N}}+\phi^{\mathrm{N}}-\mathrm{P}_{0}^{\mathrm{N}}=\frac{\sum\left(\frac{1+\kappa}{1+\kappa \psi_{1}} \tau \delta^{\mathrm{i}}+4 \theta^{\mathrm{i}}\right)}{6 \mathrm{n}}+\frac{1-\psi_{1}}{6\left(1+\psi_{1} \kappa\right)} \mathrm{T}-\frac{\sum\left(\tau \delta^{\mathrm{i}}+4 \theta^{\mathrm{i}}\right)}{6 \mathrm{n}} \\
=\frac{\kappa\left(1-\Psi_{1}\right)}{1+\kappa \psi_{1}} \frac{\sum \tau \delta^{\mathrm{i}}}{6 \mathrm{n}}+\frac{1-\psi_{1}}{6\left(1+\psi_{1} \kappa\right)} \mathrm{T}>0 \\
\left(\delta^{\mathrm{i}}-\frac{4 \mathrm{p}_{\mathrm{r}}^{\mathrm{N}}}{\tau}\right)-\left(\delta^{\mathrm{i}}+\frac{4 \mathrm{P}_{\mathrm{r}}^{\mathrm{N}}}{\tau}\right)=\frac{4}{\tau}\left(\mathrm{P}_{\mathrm{r}}^{\mathrm{N}}-\mathrm{p}_{\mathrm{r}}^{\mathrm{N}}\right)=\frac{4}{\tau}\left(\frac{\sum \tau \delta^{\mathrm{i}}}{12 \mathrm{n}}+\frac{4 \sum \theta^{\mathrm{i}}}{12 \mathrm{n}}-\frac{\sum \tau \delta^{\mathrm{i}}}{12 \mathrm{n}}-\frac{1+\psi_{1} \kappa}{1+\kappa} \frac{4 \sum \theta^{\mathrm{i}}}{12 \mathrm{n}}+\frac{\psi_{2} \mathrm{~T}^{2}}{3}\right) \\
=\frac{4}{\tau}\left(\frac{\kappa\left(1-\psi_{1}\right)}{1+\kappa} \frac{4 \sum \theta^{\mathrm{i}}}{12 \mathrm{n}}+\frac{\psi_{2} \mathrm{~T}^{2}}{3}\right)>0
\end{aligned}
$$

Ezután a hagyományos boltok profitjának különbsége már következik a második egyenlötlenségböl

$$
\Pi_{\mathrm{r}}-\pi_{\mathrm{r}}=\frac{2 \mathrm{P}_{\mathrm{r}}^{2}}{\tau}-\frac{2 \mathrm{p}_{\mathrm{r}}^{2}}{\tau}=\frac{2}{\tau}\left(\mathrm{P}_{\mathrm{r}}+\mathrm{p}_{\mathrm{r}}\right)\left(\mathrm{P}_{\mathrm{r}}-\mathrm{p}_{\mathrm{r}}\right)>0
$$

A Stackelberg esetek hasonlóak 